\title{
William Blake, religião, misticismo e poesia
}

William Blake, religion, misticism and poetry

\section{Claudio Willer}

Doutor pela Universidade de São Paulo, São Paulo, SP, Brasil

Resumo: Este artigo objetiva analisar a dimensão mística da obra de William Blake em relação a outros autores da tradição ocidental. Aqui, compreende-se misticismo à luz dos poetas e dos gnósticos, a partir de uma visão interpretativa calcada em alguns dos livros iluminados do autor. A partir de autores como Frye e Scholem, utilizo os termos de Norman Cohn "misticismo revolucionário" e "anarquismo místico", a fim de designar algumas rebeliões religiosas presentes na arte ocidental, rebeliões que encontrarão no poeta e pintor inglês uma inconfudivel marca de caracterização e aprofundamento estético.

Palavras-chave: William Blake. Gnosticismo. Poesia.

Abstract: This paper analyzes the mystical dimension of William Blake's work in relation to other authors of the Western tradition. Here, I understood mysticism in the sense used by poets and Gnostics, from an interpretive vision upon on Blake's illuminated books. From authors such as Frye and Scholem, I use the terms of Norman Cohn "revolutionary mysticism" and "mystical anarchism" in order to designate certain religious rebellions present in Western art, rebellions that find in the English poet and painter an unmistakable characterization and aesthetic depth. Keywords: William Blake . Gnosticism. Poetry.

\section{1}

Há divergências na classificação de Blake como místico. Alfred Kazin (1976), em sua importante contribuição aos estudos blakeanos, a recusa - surpreendentemente, pois transcreve depoimento de seu interlocutor Crabb Robinson, atestando o conhecimento pelo poeta da doutrina gnóstica, matriz do misticismo na tradição ocidental:

Ao obter dele a declaração de que a Bíblia era a obra de Deus, referi-me ao começo de Gênesis - "No começo Deus criou o Céu e a Terra". Mas nada ganhei com isso, pois, triunfantemente, disse-me que esse Deus não era Jeová, mas Elohim, \& 
a doutrina dos gnósticos foi repetida com suficiente consistência para silenciar alguém tão desconhecedor do assunto como eu (KAZIN, 1976, p. 274). ${ }^{1}$

E Northrop Frye, em Fearful Simmetry, estudo monumental, marco na ensaística sobre Blake, inicia a nota final com uma advertência: "A palavra "místico"" nunca trouxe nada senão confusão para o estudo de Blake". Esclarece:

Claudio Willer
Se misticismo significa em primeira instância um quietismo contemplativo, misticismo é algo execrável para Blake, uma comunhão de si-mesmo em Ulro; se significa em primeira instância uma iluminação espiritual a expressar-se em uma piedade prática e (a despeito de sua sutileza psicológica) não-especulativa, como a encontramos no monasticismo militante da Contra-Reforma, a palavra continua a não se ajustar a ele. Mas se misticismo significar em primeira instância a visão da metamorfose prodigiosa e inconcebível da mente humana que acaba de ser descrita, então Blake é um dos místicos (FRYE, s/d., p. 432).

Classificar Blake como místico dependeria, então, do que se entende por misticismo. Cabe recorrer a um especialista em misticismo, Gershom Scholem. Este deu uma resposta inequívoca: Blake representou o misticismo "sem laços com qualquer autoridade religiosa", em companhia de Rimbaud e Whitman, também "heréticos luciferianos", pois sua imaginação era "estimulada por imagens tradicionais, ou da igreja católica oficial (Rimbaud) ou de origem hermética e espiritualista, subterrânea e esotérica (Blake)" (SCHOLEM, 1965, p. 16). Scholem distingue - a propósito de Blake, Rimbaud e Whitman - duas atitudes dos místicos, uma conservadora e outra revolucionária: "uma atitude revolucionária é inevitável uma vez que o místico invalida o sentido literal das escrituras sagradas" (SCHOLEM, 1965, p. 13).

"Misticismo revolucionário", assim como "anarquismo místico", invocado por Norman Cohn para designar algumas rebeliões religiosas medievais, ou "anarquismo religioso", como é designado o

1. Também em Roelof e Hanegraaff, "Gnosis and Hermeticism from Antiquity to Modern Times", em Van den Broek, Roelof e Wouter J. Hanegraaff, Gnosis and Hermeticism from Antiquity to Modern Times. 
próprio Scholem e por um de seus estudiosos, David Biale (2004): tais termos referem-se à religiosidade fora dos quadros institucionais. Exemplifiquemos através de Walt Whitman, no prefácio da primeira edição de Folhas de relva:

Em breve não existirão mais sacerdotes. 0 trabalho deles está feito. Eles podem esperar um pouco [...] talvez uma ou duas gerações [...] sumindo gradualmente. Uma raça superior deverá tomar o seu lugar [...] as gangues do kosmos e os profetas da massa tomarão seus lugares. Uma nova ordem deve surgir e eles devem ser os sacerdotes do homem e cada homem será seu próprio sacerdote. As igrejas erigidas sob suas sombras devem ser as igrejas dos homens e das mulheres. Através da sua própria

William Blake, religião, misticismo e poesia

Nessa passagem, deu seguimento ao modo como Blake havia apostrofado a religião institucional em 0 casamento do Céu e do Inferno:

Os poetas da Antigüidade animaram todos os objetos sensíveis com Deuses ou Gênios, nomeando-os e adornando-os com as propriedades dos bosques, lagos, cidades, nações e tudo o que seus dilatados sentidos podiam perceber.

Particularmente, estudaram o Gênio de cada cidade \& país, colocando-o sob a égide de sua deidade mental.

Até que se formou um sistema, do qual alguns se aproveitaram e escravizaram o vulgo, interpretando e abstraindo as deidades mentais de seus respectivos objetos. Então surgiu o Clero;

Elegendo formas de culto dos mitos poéticos.

E proclamando, por fim, que assim haviam ordenado os Deuses.

Os homens então esqueceram que Todas as deidades residem em seus corações (BLAKE, 2007, p. 27).

Para Blake, Whitman e outros cultores das religiões pessoais, igrejas organizadas não possibilitam o acesso ao sagrado, porém o sequestram ao institucionalizá-lo e monopolizá-lo, impondo dogmas e obediência à hierarquia clerical. 
Blake, arquétipo do poeta-profeta e individualista radical, foi inassimilável não só à religião instituída, mas às seitas. Para justificar a caracterização do misticismo como religiosidade fora dos quadros institucionais, basta citar a abertura de The Everlasting Gospel:

A Visão do Cristo que tu vês

É a maior inimiga da minha visão.

A tua tem um grande nariz adunco como o teu,

A minha tem um nariz redondo como o meu.

A tua é a do Amigo da Humanidade;

A minha fala em parábolas aos cegos:

A tua ama o mesmo mundo que a minha odeia;

As portas do teu céu são os portões do meu inferno.

Sócrates ensinava o que Meletus

Detestava como a mais amarga Maldição de uma Nação,

E Caifás era em sua própria Opinião

Um benfeitor da Humanidade:

Ambos lemos a Bíblia noite e dia,

Mas tu lês negro onde eu leio branco (BLAKE, 1972, p. 748).

O que sobraria do ensinamento evangélico? Para Blake, apenas o perdão: "Não há uma Virtude Moral que Jesus Pregasse que Platão \& Cícero não houvessem Pregado antes dele; o que então Jesus Pregou? Perdão dos Pecados". Mas esse perdão, argumentou, sendo uma supressão ou esquecimento, equivale à revogação da Lei de Moisés e da idéia de pecado: "Pois Virtudes Morais todas começam/ Na Acusação de Pecado". Em consequência, o moralismo é diabólico: "Pois o que é Anticristo senão aqueles/ que contra Pecadores fecham o Céu/ Com grades de Ferro?”.

Nas experiências religiosas de caráter pessoal, o adepto ou praticante vivencia a transcendência e sente haver conseguido o acesso a um conhecimento superior. Essas são, por definição, experiências místicas, entendendo-se misticismo como a relação individual com o sagrado; e como um modo de experiência e expressão religiosa sempre na fronteira da transgressão, da ruptura com a religião normativa. Frequentemente, ultrapassando essa fronteira, caracterizando-se como heresia. Místicos são rebeldes religiosos por excelência, mesmo quando mais tarde reabilitados. Casos exemplares: o de San Juan de la Cruz, santo católico, que estava na prisão quando escreveu o Cântico Espiritual; o de Santa Tereza 
d'Ávila, canonizada, porém severamente vigiada em sua clausura pela inquisição; o de Eckhart, inicialmente tomado por mestre e depois destituído; ou, pior, o de Marguerite Porette, poeta mística medieval, queimada como herege no século 14 (TEIXEIRA, 2012)²; e, no campo protestante, o de Jacob Böhme, a quem foi imposto silêncio pelo pastor local.

Há comparações reforçadas por relações genéticas, situadas na diacronia, que se estendem dos gnósticos, dos primeiros séculos d.C, até aos contemporâneos. Havia comentado (em Um obscuro encanto e Geração Beat) o individualismo e inconformismo dos adeptos do gnosticismo, religião que associava a salvação ao conhecimento. Citei Hans Jonas: "Não-conformismo era quase um princípio da mente gnóstica, intimamente ligado à doutrina do "espírito" soberano como fonte de conhecimento direto e iluminação". (HANS, 1963, p. 42; cf. Willer, 2010, p. 38) Também me

William Blake, religião, misticismo e poesia 87 detive na controvertida questão do gnosticismo licencioso, comparando relatos sobre essa modalidade de antinomismo com adágios do tantrismo: "pelos mesmos atos que fazem queimar certos homens no Inferno por milhões de anos, o yoguin obtém sua eterna salvação". Ou: “aquele que sabe desse modo, qualquer pecado que ele pareça cometer, devora tudo e é puro, limpo, sem velhice, imortal" (ELIADE,1963, p. 262).

Interessa comparar tais transcrições com recomendações dos seguidores do Espírito Livre, uma forte rebelião religiosa medieval, citadas por Norman Cohn para ilustrar seu "total amoralismo":

\footnotetext{
O que distinguiu os adeptos do Espírito Livre de todos os demais sectários medievais foi, precisamente, seu total amoralismo. Para eles, a prova da salvação era não saber nada de consciência ou remorso. Inúmeros de seus pronunciamentos testemunham essa atitude: 'Aquele que atribui a si qualquer coisa que faça, e não atribua tudo a Deus, está na ignorância, que é o inferno. [...] Nada nas obras de um homem é dele'. E, novamente: 'Aquele que reconhece que Deus faz todas as coisas em si, esse não pecará. Pois ele não deve atribuir a si, porém a Deus, tudo o que faz'- 'Um homem que tem uma consciência é, ele mesmo, demônio, inferno e purgatório, atormentando-se. Aquele que está livre em espírito escapa de todas essas coisas.'- 'Nada é pecado exceto aquilo que é pensado como sendo pecado.'- 'Alguém
}

2. Ver o ensaio de Ceci Batista Mariani, em Faustino Teixeira (2012). 


\section{Claudio Willer}

pode estar tão unido com Deus que, qualquer coisa que faça, não poderá pecar.'- 'Eu pertenço à liberdade da natureza e tudo o que minha natureza deseja eu satisfaço [...] Eu sou um homem natural.'- 'O homem livre tem toda razão em fazer tudo o que lhe der prazer.'(COHN, 1981, p. 171).

Por isso [...] a distinção entre o Estado da Natureza, que era baseado na Lei Natural e expressado diretamente pela intenção divina, e o estado convencional, surgido e sancionado pelo costume. [...] desigualdade, escravidão, governo coercitivo e até propriedade privada não tinham lugar na intenção original de Deus e só vieram a ser como resultado da Queda. O antinomismo é, portanto, evidente: Os adeptos do Espírito Livre, por outro lado, foram intensamente subjetivos, não reconhecendo qualquer autoridade a não ser suas próprias experiências. A seus olhos, a Igreja era, quando muito, um obstáculo à salvação; na pior das hipóteses, um inimigo tirânico - em qualquer caso, uma instituição desgastada, que agora teria que ser substituída por sua própria comunidade, enxergada como vaso para o Espírito Santo (COHN, 1981, p. 150).

Interessam conseqüências extraídas por adeptos daquela "escatologia popular": [...] uma expressão dessa atitude era ainda um erotismo promíscuo e misticamente colorido [...], pois para os "sutis em espírito" a relação sexual não pode, em quaisquer circunstâncias, ser pecaminosa. [...] Alguns adeptos atribuíam um valor transcendental, quase-místico, ao próprio ato sexual, quando realizado por alguém como eles. [...] Os adeptos por vezes praticavam a nudez ritual, assim como por vezes permitiam-se promiscuidade sexual; e nos dois casos afirmavam - como um inquisidor expôs - que estavam reintegrados ao estado de inocência que havia existido antes da Queda (COHN, 1981, p. 180).

O adamismo, a prática de cultos em completa nudez, que ocorria em comunidades dos antigos gnósticos, reapareceria entre aqueles "sutis em espírito". Manifestações do que Norman Brown classificaria como "misticismo do corpo", em seu já clássico Life against Death.

A expansão do gnosticismo ocorreria no final da Idade Média, quando, observa Cohn, "Produziu-se uma doutrina que se tornou um mito revolucionário assim que foi apresentada aos pobres turbulentos 
e se fundiu às fantasias da escatologia popular" (COHN, 2010). Manifestando-se na Europa toda, o Espírito Livre viria da Espanha, onde se iniciaria por influência do sufismo; por sua vez, segundo especialistas (Hutin, Jonas, Doresse, entre outros), modalidade do gnosticismo no campo muçulmano. Como hipótese alternativa, pode ser que a origem do Espírito Livre na Península Ibérica se deva ao reaparecimento ou permanência subterrânea do priscilianismo, ramificação do gnosticismo: os adeptos do bispo dissidente Prisciliano, executado no século IV, também adotavam a ideia de uma libertação e supressão do pecado após o contato com o Espírito Santo.

No belo filme A Via Láctea de Luis Buñuel, de 1969, sobre a peregrinação a Santiago de Compostela, é mostrado um culto oficiado por Prisciliano, que se encerra com uma orgia, uma sessão de sexo coletivo;

William Blake, religião, misticismo e poesia 89 e, ainda, é declarado que a ossada lá sepultada é do bispo dissidente, e não do apóstolo Tiago. As hipóteses de que o priscilianismo foi um gnosticismo licencioso e seu líder foi enterrado em Compostela são adotadas por um estudioso do assunto, Fernando Sánchez Dragó, que também acredita em sua permanência subterrânea, como sociedade secreta: "muitos séculos depois, entrando no décimo-sexto, ainda coleavam as doutrinas do herege nada menos que na Alemanha, onde foi preciso chamar um sínodo para condená-las" (DRAGÓ, 2010, p. 38). É lícito, portanto, conectar anarquismos místicos medievais; ou, melhor, enxergar uma rede, um sistema de relações entre os retornos, no âmbito do cristianismo, de cultos arcaicos à natureza, orgiásticos; entre outros, aqueles dos celtas e druidas, como também argumenta Dragó.

Qualquer que fosse sua origem, sufista, gnóstica ou ambas, a heresia estendeu-se pela Europa toda, chegando até o norte da Alemanha, Galícia e Morávia. Seus difusores foram peregrinos autoflagelantes, begardos e beguinas. Cronologicamente, ultrapassou a Idade Média, pois durou dos séculos XIII a XVII, considerando-se (como o faz Cohn) os ranters ${ }^{3}$ ingleses - fração radical dos movimentos que resultaram na destituição e decapitação de Carlos I e na ascensão de Cromwell - como extensão.

Pode-se, portanto, enxergar relações genéticas, de transmissão ao longo do tempo, até chegar a Blake. O poeta efetivamente assimilou temas e a visão de mundo daqueles rebeldes religiosos, elaborando-os

3. A expressão ranters vem do verbo to rant: fazer um discurso sem sentido, delirar, expressar-se através de um palavrório. 
poeticamente. Tinha pleno conhecimento dos ranters, que haviam provocado enorme escândalo, inclusive pela persistência do adamismo: a tal ponto estiveram sob suspeita que, para desqualificar outras derivações religiosas, como a dos quakers, assimilavam-nas àqueles rebeldes. Além disso, ele, comprovadamente, havia estudado outras expressões da religiosidade divergente, não-institucional, levando-o a tentar realizar em sua poesia uma grande síntese de mitologias e doutrinas. Uma diversidade de estudos, desde aquele pioneiro de Frye, passando por Kazin e Van Meurs, não permite dúvidas sobre a amplidão da sua cultura.

Pansexualismo combinado a panteísmo: o que se observa no Espírito Livre e outras modalidades religiosas divergentes será reencontrado, como recomendação, nos "Provérbios do Inferno" de O Casamento 90 do Céu e do Inferno; especialmente no famoso "O caminho do excesso leva ao palácio da sabedoria“; e neste lema: "Porque tudo o que vive é Sagrado" (BLAKE, 2007, p. 31).

A propósito, o modo de interpretar Blake varia conforme o lugar, mais ou menos central, de o Casamento do Céu e do Inferno e Canções da Inocência e da Experiência. Críticos qualificados situam O Casamento do Céu e do Inferno algo à margem. Frye interpreta como sátira na tradição de Swift e Sterne: "O Casamento do Céu e do Inferno pertence à tradição da grande sátira" (FRYE, s./d., p. 200). Para Cazamian, é paródia de Swedenborg. Ver ironia e paródia nessa obra, como o faz também Keynes, organizador de Complete Writings, justifica-se pelo modo como critica a Swedenborg após referir-se ao visionário como mestre e profeta. É um bom exemplo de seu gosto pela contradição: "Não há progresso sem Contrários. Atração e Repulsão, Razão e Energia, Amor e Ódio são necessários à existência Humana" (BLAKE, 1972, p. 149).

Interpretar 0 Casamento do Céu e do Inferno como paródia satírica é reduzir a importância e o alcance dessa proclamação tão libertária e precursora. Já Octavio Paz toma O Casamento do Céu e do Inferno como obra central, ao apresentar Blake como representante destacado da rebelião romântica:

A figura de William Blake condensa as contradições da primeira geração romântica. Condensa e as faz arrebentar em uma explosão que vai além do romantismo. Foi um verdadeiro romântico? O culto da natureza, que é um dos rasgos da poesia romântica, não aparece em sua obra. Acreditava que "o mundo da imaginação é o mundo da eternidade, enquanto o mundo da geração 


\begin{abstract}
é finito e temporal". Esta idéia o aproxima dos gnósticos e dos iluminados, mas seu amor ao corpo, sua exaltação do desejo erótico e do prazer - "aquele que deseja e não satisfaz seu desejo engendra pestilência" - o colocam contra a tradição neoplatônica. Embora se chamasse 'adorador de Cristo', foi cristão? Seu Cristo não é o Cristo dos cristãos: é um titã nu, que se banha no mar radioso da energia erótica. Um demiurgo, para quem imaginar e agir, desejar e satisfazer o desejo são uma única e a mesma coisa. Seu Cristo lembra mais o Satã de The Marriage of Heaven and Hell (1793): seu corpo é como uma gigantesca nuvem iluminada por relâmpagos incessantes: a escritura chamejante dos provérbios do Inferno (PAZ, 1984, p. 76).
\end{abstract}

Paz foi, ele mesmo, seguidor de Blake, nem tanto no plano estritamente literário, mas no modo de pensar. Reconheceu a importância de $O$ Casamento do Céu e do Inferno em sua formação. Em Os Filhos do Barro, faz afirmações que correspondem, de modo literal, àquelas de Blake: "Sem a imaginação poética não haveria nem mitos nem sagradas escrituras; simultaneamente, desde os primeiros tempos, a religião confisca para seus fins a imaginação poética" (PAZ, 1984, p. 74). O trecho é paráfrase de All Religions are One: "As religiões de todas as Nações são derivadas da diferente recepção em cada Nação do Gênio Poético, que, em todo lugar, é chamado de Espírito da Profecia" (BLAKE, 1972, p. 98).

\section{2}

Mais importante que constatar continuidade e influências de uma etapa de rebeliões religiosas sobre outra, subsequente, é observar seu fundamento filosófico; a matriz partilhada por elas. Essa consiste na crítica, ou melhor, em uma dupla crítica, imanente e transcendente. Imanente, por dirigir-se contra a ordem estabelecida, os poderes vigentes em um dado momento. Transcendente, por expressar uma cosmovisão segundo a qual a realidade imediata, sensível, é falsa, devendo ser substituída por um mundo melhor, mais justo e harmônico; pela reconquista do paraíso perdido, do estado adâmico. Tais idéias são recorrentes e, sem dúvida, trans-históricas e transculturais. Expressam-se através da associação óbvia da pobreza à santidade; e da santidade, uma condição espiritualmente superior, à liberdade. Para os transgressores religiosos, trata-se de liberdade no mundo, permissão para fazer tudo. É o que sugere a presença das místicas da transgressão
William Blake, religião, misticismo e poesia 
em contextos tão diversos, da Antiguidade até hoje, do Tibete até nossas imediações, das sociedades tribais até os núcleos nas metrópoles.

Gary Snyder, poeta beat, adepto do budismo, e estudioso sistemático de religiões e cultos arcaicos, observou essa continuidade:

Claudio Willer
De certo modo, pode-se ver a geração Beat como um outro aspecto da perpétua "terceira força" que tem avançado através da história com seus próprios valores de comunidade, amor e liberdade. Pode ser relacionada às antigas comunidades dos essênios, ao cristianismo primitivo, às comunidades gnósticas e às heresias do espírito livre da Idade Média; com o sufismo islâmico, o taoísmo chinês primitivo, e com ambos os budismos, zen e shin. As audaciosas e tocantes esculturas eróticas em Konarak, na Índia, as pinturas de Hieronymus Bosch, a poesia de William Blake, tudo isso pertence à mesma tradição. $O$ lema num café Beat em Los Angeles é a equação “Arte é Amor é Deus”. Na América nós recebemos isso de Walt Whitman e Henry David Thoreau e dos professores da geração anterior à nossa, William Carlos Williams, Robinson Jeffers, Kenneth Rexroth, Henry Miller e D. H. Lawrence (SNYDER, 2005, p. 184).

O núcleo inicial da geração beat, tal como constituído em 1944, com Ginsberg, Kerouac, Lucien Carr, William Burroughs e amigos, procurou alcançar a "nova visão", uma ampliação da percepção ou transformação da subjetividade. Fundamentavam-se em poetas que se relacionaram com tradições esotéricas, especialmente, Blake, Rimbaud e Yeats. É emblemático que Carr, preso e julgado por cometer um assassinato no final de $1944^{4}$, tivesse uma foto publicada em jornais mostrando-o, ao comparecer ao tribunal, com um exemplar de A Vision de Yeats: a obra mais especificamente esotérica do poeta irlandês, adepto do ocultismo, que lhe teria sido ditada por sua mulher em transe; resultado, segundo ele, da "escrita automática".

Yeats, mesmo partilhando com os beats a reverência por Blake - tomava-o como paradigma, situando-o acima de fontes especificamente ocultistas até em sua participação nas polêmicas no âmbito da ordem esotérica da qual fazia parte, como se vê por sua correspondência (HARPER, 1974) $)^{5}$ - dificilmente endossaria o modo como aquele

4. Esfaqueou David Cammerer, homossexual que o assediava e que o vinha seguindo onde quer que fosse desde seus 14 anos de idade.

5. Especialmente em Yeats's Golden Dawn, de George Mills Harper. 
grupo interpretou suas investigações ocultistas: "disciplina" e "ordem" são palavras-chave em suas manifestações no âmbito daquela sociedade secreta.

Diários e poemas de Allen Ginsberg mostram-no como um visionário obcecado pela transcendência, por mistérios cósmicos, o sentido da vida e da existência, a natureza de Deus. Dentre os integrantes da Geração Beat, foi aquele que teve a relação mais intensa com Blake. Em entrevistas, depoimentos e palestras, apontou como experiência marcante e decisiva sua "iluminação auditiva da voz de William Blake simultaneamente com a visão da eternidade" de 1948: ouviu uma voz, que seria a do próprio Blake, dizendo os poemas que lia, "The sick rose" ("A rosa doente") e "Ha! Sunflower" ("Ah! Girassol”) de Canções da Experiência, enquanto se masturbava distraidamente, acompanhada pela

William Blake, religião, misticismo e poesia 93 sensação de beatitude e uma percepção muito aguda da paisagem urbana vista da janela de seu apartamento. Como relatou em sua entrevista à Paris Review:

\begin{abstract}
Na verdade, o que eu acho que fiz foi engatinhar pela saída de emergência até o apartamento de umas meninas que moravam ali. Eu bati na janela delas e disse "Eu vi Deus", e elas fecharam a janela imediatamente. Ah! Quantas histórias eu podia ter contado se elas me tivessem deixado entrar! Porque eu estava num estado mental muito exaltado e a consciência ainda estava comigo - eu me lembro de que imediatamente fui correndo para Platão e li uma bela imagem no Fedro sobre cavalos voando pelo céu, e depois corri para São João e comecei a ler fragmentos de con un no saber sabiendo... que me quede balbuciendo, $\mathrm{e}$ depois fui para outra parte da estante e peguei Plotino falando sobre O Solitário - o Plotino eu achei mais difícil de interpretar (COHN, 2010, p. 149).
\end{abstract}

Impressiona a sequência: Ginsberg ouviu Blake, proclamou que viu Deus e leu a fundamentação filosófico-religiosa daquela experiência em Platão, Plotino e San Juan de La Cruz. Condensou uma poética e uma mística.

O uso do vocabulário religioso ou litúrgico por Kerouac, Ginsberg, para descrever encontros com jazzistas, já foi visto como exagero e cacoete. No entanto, como observado por Scholem, a fala de Deus é sonora e não-significativa, assim mostrando o sentido profundo dessas atribuições. Ginsberg o sabia desde 1948, ao ter a "iluminação auditiva de William Blake". 
As experiências de Ginsberg com alucinógenos foram, durante um período, tentativas de reviver aquela iluminação, experimentando a mesma beatitude. Assemelhavam-se a teofanias, porém marcadas pela heterodoxia e pluralismo religioso, como enfatizou em seu poema "Kral Mahales" de 1965, o relato de sua expulsão da Tchecoslováquia após ser coroado "rei de maio" (kral mahales no idioma tcheco) e promover escândalos: "e eu sou o Rei de Maio, naturalmente, pois eu sou de descendência eslava e um judeu budista/ que cultua o Sagrado Coração de Cristo o corpo azul de Krishna as costas retas de Ram/ as contas de Xangô o nigeriano cantando Shiva Shiva em um modo que inventei" (GINSBERG, 1988, p. 354). É a religião total: o culto a todos os deuses de todas as crenças. $E$ também a heresia total, sob o ponto de vista das religiões institucionais, oficiais.

Em outras ocasiões, como na palestra "Gnostic consciousness" (GINSBERG 1974$)^{6}$, observou a relação de continuidade a partir de Blake, passando por Whitman e chegando até ele. Outros beats insistiram nessa relação com Blake; Michael McClure, por exemplo, ao equiparar o "eu" profundo a um mamífero, e não a uma entidade espiritual, extramundana ou supraterrena:

\footnotetext{
QUANDO UM HOMEM NÃO ADMITE SER UM ANIMAL, ele é menos que um animal. O grande MAMÍFERO William Blake é importante pela beleza que apresenta, pela clareza da sua visão e pelo seu exemplo. [...] O HOMEM NÃO É UM ISÔMERO DE MAMÍFERO - ele é precisamente um mamífero. A rota para essa consciência é necessariamente biológica. A poesia é biológica. [...] o homem é um mamífero se experimentando (MCCLURE, 2005, p. 219).
}

Com essas afirmações, segue o Blake de 0 casamento do céu e do inferno e vários outros escritos, inclusive o antológico poema sobre o tigre:

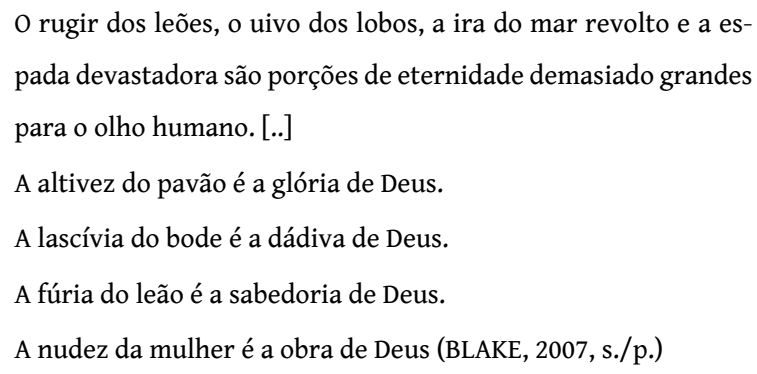

6. Publicada em Lectures on Poetry, Politics, Consciousness de Allen Ginsberg. 
Cabe alguma reflexão sobre o sentido dessa religiosidade e misticismo em poetas pós-iluministas, beats inclusive. Pode corresponder a um terceiro estágio ou nova fase das relações entre religião, política e sociedade. Após o absolutismo da Contra-Reforma e sua derrocada com a destituição de Deus, substituído pelo culto à razão promovido pelo Iluminismo, é possível registrar o retorno, não mais exclusivamente daquele Deus da religião institucional, porém dos deuses, celebrados através de uma diversidade de cultos e doutrinas.

Seria o que Spengler, em A decadência do Ocidente, chamou de "segunda religiosidade" (SPENGLER, 1964). Para o historiador, uma etapa correspondente ao declínio de civilizações, e, na civilização ocidental, da "concepção mecânica do mundo" e do "materialismo":

O que vem depois é aquilo que denomino de segunda religioWilliam Blake, religião, misticismo e poesia sidade. Ela aparecerá em todas as civilizações, logo que essas, após terem alcançado a plenitude do seu desenvolvimento, entrarem naquele estado não-histórico para o qual os lapsos de tempo já não significam nada. A segunda religiosidade é o equivalente necessário do cesarismo, definitiva constituição política das civilizações posteriores (SPENGLER, 1964, p. 370).

Kerouac chegou a declarar, em "The origins of the Beat Generation", artigo de 1959, que a Geração Beat correspondia à "segunda religiosidade" de Spengler. No entanto, embora conhecesse bem as categorias de Spengler, aplicando-as ao "estágio tardio da civilização, quando o dinheiro é a única coisa que importa", sua interpretação foi pessoal. 0 modo como o pensador da decadência examinou manifestações de uma nova religiosidade foi crítico e depreciativo. Precedem-na, para Spengler,

[...] no atual mundo europeu-americano as burlas ocultistas e teosóficas, a Christian Science ianque, o mendaz budismo de salão, a indústria religiosa, que, na Alemanha ainda mais que na Inglaterra, promove-se por meio de seitas e cultos, em rodas góticas, antiquizantes e taoístas (KEUROUAC, 1959, s./ p.).

Faltariam à "segunda religiosidade" e manifestações que a precedem "a força criadora primitiva, das culturas jovens". E, nessa "fase tardia", a fé "torna a patentear-se vigorosamente num sincretismo popular, que todas as culturas, inevitavelmente, produzem a essa altura da sua evolução". 
Observar a reaparição de religiões e cultos, mitos e superstições em finais de épocas e períodos de mudança - ou "decadência" - é correto. Mas o julgamento de Spengler é simplificador, assim como aqueles de outros tradicionalistas. Mircea Eliade também via ocultismos modernos como manifestações degradadas do arcaico. Observou o "número considerável de seitas ocultas, sociedades secretas, grupos pseudo-iniciáticos, movimentos hermetistas, neo-espiritualistas etc" (ELIADE, 1999, p. 279). Classificou-as, à exceção da maçonaria, como "improvisações recentes e híbridas" que "ilustram a desorientação de uma parte do mundo moderno, o desejo de encontrar um substituto à fé religiosa" (ELIADE, 1999, p. 279).

Mas a religiosidades beat e de outros poetas, inclusive a réplica esdrúxula e desordenada de um círculo esotérico pelos adeptos da "nova visão", certamente foi além dessa caracterização. Spengler foi redutor ao vê-la apenas como fenômeno característico da decadência, e não como emergência do novo. Deixou de levar em conta seus correlatos artísticos e literários. Tomando exemplos dentre os contemporâneos de Spengler, aquilo de que Yeats participou foi, de modo evidente, ocultismo de salão. $O$ extraordinário poeta alemão Stefan George liderou uma dessas "rodas góticas antiquizantes". Antes, Victor Hugo se maravilhara com o repertório completo de cultos e manifestações do sobrenatural que o século XIX lhe oferecia. O mesmo já podia ser observado a propósito de Gérard de Nerval. Ou em Fernando Pessoa, porém em uma relação complexa de fascinação ambivalente.

Não obstante, a criação literária mais estreitamente ligada a tais crenças e frequentações foi, no caso desses autores, poderosa - assim como aquela de expoentes do simbolismo-decadentismo que também frequentaram o típico ocultismo de salão do Sär Péladan e outros chefes de seita.

Eliade observou, com razão, que "aquelas obras modernas nas quais se pode decifrar os temas iniciáticos - por exemplo: Ulisses de James Joyce, The Waste Land de T. S. Eliot" (ELIADE, 1999, s./p.) foram criadas por escritores que não mantinham relação com grupos ocultistas. Mas a recíproca não é verdadeira: houve, sim, criações literárias importantes (e de outros campos, é claro) por autores diretamente envolvidos com esoterismo.

A "segunda religiosidade" de Spengler encobre manifestações distintas; ou, em alguns casos, refere-se à mesma manifestação, porém com sentidos distintos em função de quem é seu adepto ou frequentador. Kerouac (1959), no artigo citado, mesmo expressando a crença no inevitável 
fim da civilização ocidental, soube observar tais diferenças. Não falava mais de uma religiosidade tardia, e menos ainda decadente, porém da recuperação daquela fundadora ou iniciadora, como o foi (para Spengler, cabe insistir) durante o gótico medieval, e, em certa medida, a que constituiu os Estados Unidos. Distinguindo-se do catolicismo romano, inexiste um comando central no campo aberto pela reforma protestante. Por isso, nunca foi homogêneo, porém dividido em algumas grandes denominações e inúmeras denominações menores, além das seitas autônomas.

Cabe mencionar que "religiões pessoais" é o termo usado por Kirby Olson, remetendo com propriedade a Friedrich Schlegel e à primeira geração romântica. O comentário desse ensaísta é sobre Corso, mas pode ser aplicado a outros integrantes daquele movimento: Schlegel escreveu: "Apenas aquele que tem uma religião de si mesmo e uma concepção original do infinito pode ser um artista" (SCHLEGEL apud OLSON, 2002, p. 66).

Um dos aspectos dessa diversidade religiosa pós-iluminista corresponde ao que Octavio Paz chamou, em Os Filhos do Barro, de "Religiões românticas: heresias, sincretismos, apostasias, blasfêmias, conversões", referindo-se às devoções de Novalis e Nerval (PAZ, 1984, p. 69). Novalis chegou a apresentar Jesus Cristo, em um de seus Geistliche Lieder (Cânticos Espirituais), como restaurador do panteísmo pagão. Nerval declarou professar dezesseis religiões e identificava, em um sincretismo total, Jeová e Júpiter, titãs e amalecitas em As Quimeras, e sua amada Jeny Collon à Vênus, à Isis e à Virgem em Aurélia.

Uma abordagem semelhante é proposta por um autor mais recente, Roberto Calasso, em A literatura e os deuses, banidos pelo cristianismo e subsequentemente pelo cientificismo, antigos deuses pagãos retornam através do que esse ensaísta chama de "literatura total", fazendo-se presentes em Baudelaire, Lautréamont, Mallarmé e outros modernos (CALASSO, 2004). Algo bem distante, portanto, da piedade popular observada por Spengler ao escrever sobre a "segunda religiosidade".

Assim como o anarquismo predominante entre os beats se apresentou como alternativa à dualidade da Guerra Fria no campo da ideologia política, o mesmo ocorreu com crenças religiosas. Diante dos dois blocos, do monoteísmo institucional e do materialismo ortodoxo, apresentaram o que Snyder caracterizou como "terceira via": da religião pessoal, do sincretismo, do pluralismo, da heterodoxia e da liberdade, inclusive no modo de relacionar-se com a esfera transcendental ou com as camadas mais profun- 
das do próprio ser. Importa destacar que, de modos diferentes, Blake foi reconhecido como expressão máxima, o grande profeta, dessa nova religiosidade heterodoxa e desse msiticismo transgressivo.

\section{3}

Ao sustentar a realidade de suas visões, Blake formulou uma poética do delírio. Considerá-lo louco equivale a depreciá-lo, e seria injusto, por ignorar que concluiu Jerusalém e The Everlasting Gospel no mesmo ano de 1820: um poema exorbitante em matéria de simbolismo, que pode ser classificado como delirante, e o outro, bem linear, de pura argumentação, sem nenhum personagem de sua mitologia particular. The Everlasting Gospel não contradiz Jerusalém: ambos se complementam, extraindo-se uma doutrina de um desses poemas, será confirmada pelo outro.

Mas a recíproca, normalizar Blake, também é redutora. Loucura e criação não são incompatíveis: Gérard de Nerval teve crises e surtos que resultaram não só nas experiências de "efusão do sonho na vida real" (NERVAL, 1995, p. 28) relatadas em Aurélia, mas em sonetos de As Quimeras. Comentou, ironicamente: "Recobrando o que os homens chamam de razão, não deveria eu lamentar tê-la perdido?” (NERVAL, 1995, p. 35). Interessa sua noção de efusão ou transbordamento do sonho, tomando conta da realidade. Uma coisa é a transcrição de um sonho ou o relato de um delírio, outra, sua efusão, que pode resultar em uma epopeia como Vala or The Four Zoas, com suas 120 páginas na edição Keynes, à qual Blake deu o seguinte subtítulo: um SONHO de Nove Noites, intitulando ainda cada uma das nove partes como Noite a primeira, Noite a segunda etc. - reproduzindo em um modo extremo a valorização romântica do sonho, tão precursora do surrealismo.

Não só essa epopeia, como seus demais poemas requerem leitura e interpretação através do que se sabe sobre a "lógica" do sonho, especialmente, sobre o deslocamento. No sonho, é possível um enredo no qual Jesus Cristo comparece como salvador, para tornar-se Lúcifer, e esse transformar-se em Jeová, que por sua vez é alguém que conhecemos, e logo é outro personagem, enquanto vão mudando a cena e as situações nas quais isso ocorre. Há instabilidade dos símbolos: o mesmo pode significar coisas distintas, assim como vários símbolos significam a mesma coisa; o sentido é múltiplo. A instabilidade não é "ilógica“: tanto é que Frye foi capaz de construir um diagrama, dando conta das mutações em Vala or The Four Zoas. Mas, isso não permite dizer que esse poema não fosse delirante: delírios têm lógica; mas é uma lógica própria. 
Em Vala or The Four Zoas e outras das suas obras, há, não só polissemia, mas um universo multidimensional que desconhece os princípios lógicos da identidade e não-contradição. Assim como no sonho, os símbolos flutuam na relação com o que significam. É seu infinito, visto em cada coisa quando as portas da percepção estão abertas, relatado deste modo em Milton:

Esta é a Natureza do infinito:

Todas as coisas possuem seus próprios Vórtices, e quando um navegante da Eternidade

Passa este Vórtice, percebe que ele turbilhonante gira para trás

E penetra numa esfera que se engloba a si mesma como o sol, a lua, ou como um firmamento de constelada magnitude

Entretanto prossegue em sua maravilhosa trajetória pela terra,

Ou como forma humana, um amigo com o qual pode-se compactu-

ar luminosamente a existência.

O olho humano, seu Vórtice abarcando, vislumbra o leste \& o oeste O norte \& o sul, com suas vastas legiões de estrelas

O sol surgente e a lua no fulcro do horizonte

Os seus milharais e vales de quinhentos alqueires

A terra é uma planura infindável, e não como aparece

Ao ignóbil transeunte confinado às sombras da lua.

O céu é um Vórtice já há muito transpassado;

A terra, um Vórtice ainda intocado pelos navegantes da Eternidade (BLAKE, 2007, p. 84).
William Blake, religião, misticismo

e poesia

Blake afirma que, através da imaginação, pode-se atravessar os vórtices, viajando por um universo que não corresponde mais ao que captam os cinco sentidos. Deixa de haver diferença entre subjetividade e objetividade; se a terra é redonda, plana e infinita; lugares do céu e da terra, o alto e o baixo, podem ser trocados; e o corpo humano contém o universo assim como, reciprocamente, o universo tem forma de corpo humano. São levados a extremos o pensamento analógico e a ideia das correspondências entre macrocosmo e microcosmo. A substância é abolida, substituída pela relação. Blake representou através do desenho, em Milton, de uma topologia, um mapa do cosmo revelado a Milton e por ele percorrido, no qual entidades míticas: Adão, Satã, Luvah, Tharmas, Urthona e Urizen, são regiões; mas, ao mesmo tem- 
po, são estados e se sobrepõem. Assim, a mesma região central é Adão quando sobreposta a Urthona, um estado primordial, e Satã quando sobreposta a Urizen, a razão fantasmagórica.

Não lhe bastavam as correspondências entre duas esferas, o alto e o baixo, como no hermetismo: o real é feito de relações múltiplas, em uma colossal combinatória do particular e do universal, do transcendente e do imanente, do humano e do cósmico. Como expôs nestes trechos vertiginosos de Milton:

\section{Claudio Willer}

100

\section{Toda fração de Tempo menor que um pulsar de artéria}

Equivale a Seis Mil Anos.

Pois neste Ciclo é criada a obra do Poeta, e nele os Grandes Eventos do Tempo se iniciam e são concebidos

No fulcro de um instante, Pulsação arterial.

O céu é uma Tenda Eterna erguida pelos Filhos de Los;

E o vasto Espaço que o Homem contempla em sua morada

Na cobertura ou jardim no cimo de uma colina

De vinte e cinco pés de altura, é seu Universo; [...]

Tal é o espaço denominado Terra \& tal sua dimensão

Enquanto essa falsa aparência que se apresenta ao racionalista

Como um Globo rolando através da Vacuidade, é uma decepção de Ulro.

E disto nem desconfiam o Telescópio ou o Microscópio;

Alteram os parâmetros dos Órgãos do Espectador, deixando intocados os objetos;

Pois cada Espaço maior que um Glóbulo vermelho de sangue Humano É visionário e foi pelo martelo de Los criado.

E cada espaço menor que um Glóbulo de sangue estende-se Às larguras da Eternidade, da qual esta terra

Vegetal não é senão a mera imagem.

O Glóbulo vermelho é o insondável Sol por Los criado,

Para mensurar o Tempo \& o Espaço aos Mortais a cada manhã (BLAKE, 2007, p. 86-88).

Tais passagens estão além do relato de sonhos, a exemplo daqueles de Jean-Paul Richter. Se o que lembramos e relatamos como sonhado é o resultado da seleção e elaboração através do pré-consciente, então poemas mais complexos de Blake correspondem ao sonho originário, o urgrund do onírico, anterior à elaboração. É a simbolização desnudada. 
Ninguém sonha no vazio: assim como toda escrita é intertextual, relacionada a alguma leitura, o sonho incorpora e elabora a experiência, o que Freud chamou de "restos do cotidiano". Se o sonhador for um leitor, elabora suas leituras. Sonhos preservam estilos literários: os sonhos que Breton transcreveu são surrealistas; os que foram publicados de Kerouac e Ginsberg são beat; Jean-Paul Richter e Hoffmann tiveram sonhos românticos. O que Blake conhecia de religião e mitologia está presente, elaborado, em sua poesia. Em especial, sua representação do tempo, na qual convergem distintas concepções da temporalidade. Sintetizou dois grandes modos de perceber o tempo, um deles circular, outro linear, em uma sucessão de ciclos que também é movimento progressivo. 0 modelo mais afim seria, como observado por Frye, aquele das grandes epopeias do hinduísmo tardio, com

William Blake, religião, misticismo e poesia seus ciclos cósmicos, e, na tradição ocidental, as eras precedendo um mundo melhor conforme o místico Joachim de Fiore. É o que Blake expõe em Milton:

E os quatro estados da tranqüila Humanidade em seu Repouso

Foram-lhe então mostrados. Primeiro o de Beulah, o gostoso Sono Sobre os sedosos leitos ao suave modular das melodias e das Flores de Beulah

Doces formas Femininas aladas ou flutuantes no cristal do ar. O Segundo Estado é Alla \& o terceiro Al-Ulro.

Mas o quarto, o fantástico, é denominado Or-Ulro.

O Primeiro localiza-se na Cabeça, o Segundo no Coração

O Terceiro nos vasos seminais e o Quarto, No Estômago e Intestinos, terrível, letal e indescritível. E aquele, cujos Portais se abrem nessas regiões do Corpo, Pode nestes Portais vislumbrar estas deslumbrantes Imaginações (BLAKE, 2007, p. 78).

No entanto, há uma diferença com relação às representações do universo regido por ciclos. Blake não fala de períodos, mas de extensões temporais que também são espaciais e, além disso, estados ou condições: os eons do gnosticismo. Apenas a imaginação é estável. Matriz da criação, isso equivale ao Adam Cadmon, o homem pleno. Conforme a fala dos Sete Anjos a Satã, em Milton: 
A Imaginação não é um Estado: é a própria Existência Humana.

Afeição ou Amor tornam-se um Estado quando divididos da Imaginação.

A Memória é um Estado sempre, \& a Razão é um Estado

Criado para ser Aniquilado e uma nova razão ser Criada.

Tudo o que pode ser Criado pode ser Aniquilado: Formas não podem:

o Carvalho é abatido pelo Machado, o Cordeiro cai pela Faca,

Mas suas Formas Eternas Existem Para-sempre. Amem. Aleluia!

(BLAKE, 1972, p. 522)

Claudio Willer

102

Ao reapresentar o cosmo regido por ciclos, Blake não aceitou uma de suas consequências: a doutrina da predestinação. Menos ainda, as reencarnações. O homem - o homem total, Antropos - não é objeto, mas sujeito do movimento cíclico.

Nada a estranhar nos vórtices, na extensão temporal contida em um glóbulo de sangue, nos patamares de tempo e espaço de Milton: trata-se de esclarecimento, por alguém que acreditava "Num grão de areia ver um mundo" e segurar "o infinito em sua mão"; para quem a eternidade podia "caber em um segundo". Em Milton e Jerusalém, Blake relatou como seriam o infinito e a eternidade.

Aquele final do século XVIII e início do XIX já conhecia Leibnitz, com sua representação do universo em mônadas, seu débito para com os eons do misticismo judaico-helenista, sua invenção do cálculo infinitesimal e da análise combinatória. Böehme exercia influência em meios cultos. Estudava-se Kant. Representações de um cosmo multidimensional, relativizando espaço e tempo, sujeito e objeto, eram formuladas sincronicamente no âmbito da primeira geração do romantismo alemão, como se vê em Novalis:

\footnotetext{
Tempo e espaço vêm a estar juntos e daí provavelmente serem um, como sujeito e objeto. Espaço é tempo duradouro - tempo é espaço fluido, variável. Espaço - a base de tudo o que é duradouro - tempo - a base de tudo que é mutável. Espaço é o esquema - tempo o conceito - a ação (gênese) desse esquema. A cada momento meu pensamento deve acrescentar um momento antes e depois (NOVALIS, 1997, p. 134).
}

Apesar dessa especulação avançada, o mundo, para os contemporâneos mais cultos e esclarecidos de Blake, correspondia às informações recebidas através dos sentidos, e podia ser descrito através da geome- 
tria euclidiana e da física newtoniana. Imagine-se a perplexidade diante de obras cuja interpretação requer paradigmas que se tornariam plausíveis no século XX.

Talvez a complexidade e natureza torrencial da simbologia e representação do universo de Blake fossem tentativas de resolver incompatibilidades, não só entre utopia e realidade, mas entre monismo e dualismo: entre Urizen e o Deus da natureza viva de 0 Casamento do Céu e do Inferno. Em especial, pode-se interpretar a poesia de Blake como resposta a um debate filosófico de enormes consequências, entre empirismo e idealismo; a crença no "real" imediato, ou sua crítica; entre Locke, a quem Blake execrava, e Berkeley, por quem manifestou admiração, inclusive, como demonstra Van Meurz, por partilharem fontes e influências herméticas (ROELOF; HANEGRAFF, 1998, p. 276) . Blake procurou

William Blake, religião, misticismo e poesia uma resposta mitopoética, para além do empirismo e do idealismo.

Poetas podem ser mais complexos que profetas e reformadores religiosos. Blake o comprova. Pode-se vê-lo como criador de representações do universo, das quais aquela dualista do gnosticismo seria caso particular, uma das suas possibilidades. O mundo imerso no sono de Ulro, regido pelo demiurgo e por arcontes, com a separação entre bem e mal, luz e sombra, é um dos estados do universo blakeano. Como observei em Um obscuro encanto, a obra de Blake é afim ao gnosticismo, e também ao conjunto de obras proféticas ou visionárias daso quais doutrinas gnósticas fazem parte, incluindo o que as precede, mitologias arcaicas e antigas doutrinas de salvação, e aquilo que as antecede diretamente, a especulação religiosa do Oriente Próximo na Antiguidade tardia; e o que está a seu lado, que lhe é paralelo: doutrinas e mitologias da Índia; e seu prosseguimento em heresias medievais e da Renascença.

Isso não impede que se apontem diferenças importantes entre Blake e o gnosticismo. Uma delas, nunca haver adotado a separação entre eleitos e o restante da humanidade. Em seu universalismo místico e poético, "Todos os homens são iguais, embora infinitamente vários, Assim (e com a mesma infinita variedade), todos são iguais no Gênio poético" (BLAKE, 1972, p. 98). Por isso, não poderia haver predestinação, nem seria admissível a doutrina protestante da Graça, tão seletiva.

Em um paradoxo que pode surpreender, Deus está pouco presente na poesia "simbólica" de Blake. Há deuses, e Jeová é um deles com uma dupla significação, como Deus eterno e como Jeová Elohim, o deus do mundo, como observa Van Meurs (ROELOF; HANEGRAFF, 1998, p. 307), Jesus Cristo é especialmente importante. Satanás também com- 
parece, como personagem e adjetivo. Demiurgos não faltam - mas Blake não parece interessar-se pelo En-Sof, o Logos, o Princípio Primeiro, a esfera onipresente do Pseudo-Dionísio Areopagita e de tantos outros místicos. Jeová e o Deus-pai da teologia cristã colidiriam frontalmente, é claro, com seu anti-autoritarismo: são o Deus da Lei. Onde Blake mais fala em Deus é nos textos panteístas, como o Casamento do Céu e do Inferno: mas é o Deus que se confunde com o mundo, ao mesmo tempo logos, pneuma e soma.

No centro do universo de Blake, no lugar de Deus está o homem. Não o homem mundano, porém o Antropos, equivalente ao universo. Suas epopeias são relatos da perda e reconquista da plenitude.

Blake é complexo por ser um poeta do final do século XVIII, atento aos debates de seu tempo. Dispunha de outro repertório, mais refinado do que aquele dos profetas da Antiguidade. Não buscou o conhecimento abstrato, porém a vida. Não aspirava à salvação, porém à liberdade; confundia salvação e liberdade, entendendo-a como liberdade de criar, e não só como libertação do mundo, como reafirmou em Jerusalém:

\footnotetext{
Não sei de nenhuma outra Cristandade e de nenhum outro Evangelho a não ser a liberdade de ambos, corpo \& mente, para exercer as Divinas Artes da Imaginação, Imaginação, o Mundo real \& eterno do qual este Universo Vegetal não passa de uma sombra fugidia, \& no qual viveremos em nossos Corpos Eternos ou Imaginativos quando estes Corpos Mortais Vegetais não mais existirem. Os Apóstolos não conheciam nenhum outro Evangelho (BLAKE, 1972, p. 716).
}

Há uma resposta ao dualismo nessa passagem: a liberdade de ambos, corpo \& mente. Talvez se referisse às doutrinas platônicas ao falar em sombra fugidia neste Universo Vegetal, caído. Mas no centro não está mais o logos impessoal, porém a imaginação, entendida do mesmo modo como a celebravam Coleridge, Wordsworth, Novalis e Baudelaire, que a chamou de rainha das faculdades: faculdade evidentemente humana, e também divina; ou correspondente ao divino no humano. Para um gnóstico da Antiguidade tardia, o conhecimento era intransitivo, absoluto; mas a liberdade era transitiva: liberdade para sair do mundo e deixar de existir como indivíduo. Para Blake, o conhecimento era intransitivo, total, e também o era a liberdade. 
Passagens como essa aqui citada, do final de Jerusalém, sugerem um caminho para interpretar sua aparente duplicidade de visões de mundo, opondo 0 Casamento do Céu e do Inferno à poesia "simbólica": o tigre é divino, assim como o rugir dos leões e a nudez da mulher; e tudo isso faz parte deste mundo, mas desde que iluminado e transfigurado pela imaginação. O Paraíso é aqui; está no grão de areia, porém apenas homens e mulheres livres saberão enxergá-lo.

Insurgiu-se contra o estado vegetativo, o sono de Ulro, a perda no mundo vegetal, por corresponderem à queda da vitalidade. Daí resulta uma doutrina da salvação que nunca poderia corresponder ao desaparecimento do indivíduo, à fusão no estado indiferenciado. A salvação não é saída do mundo, mas restauração: o novo mundo, como é dito no final de Vala or The Four Zoas, onde "a doce Ciência reina".

William Blake, religião, misticismo e poesia

Seu sincretismo criativo o identifica ao romantismo, resultando não só na fusão de doutrinas e mitologias, mas na criação de novas entidades e categorias. Um hiper-sincretismo, no qual mitos de diferentes religiões passam a interagir com personagens históricos: Milton, Newton, Locke e Franklin. Confusão dos dois planos, com a reinterpretação mitológica do histórico, é algo tão antigo quanto a Bíblia e a epopeia, passando por Dante e Camões. Mas, em Blake a inclusão de eventos e personagens históricos representa o espírito romântico; a época na qual a história parecia bater à porta dos poetas, convocando-os imperiosamente. 0 modo como, para atender a essa convocação, converteram acontecimentos políticos em teodiceias compõe um ciclo que vai de Blake ao Victor Hugo de La légende des siècles.

Não é coincidência um período especialmente produtivo de Blake corresponder aos anos que medeiam entre a Queda da Bastilha e o Diretório. Naqueles anos, algo de novo acontecia na esfera política. Para os profetas dos primórdios da era cristã, a sensação de urgência de um apocalipse decorria de uma intolerável repetição: a cada Calígula sucedia-se um Nero; a cada Vespasiano, um Adriano. Entre os poetas do final do século XVIII, a sensação de urgência era provocada pela impressão de que o milênio se completara e o apocalipse já estava acontecendo nas ruas parisienses.

Para Blake, religião era manifestação do gênio poético. Coincidiu com Novalis e seus companheiros do círculo de Jena: queriam, mais que uma poesia religiosa, uma religião da poesia. Foi o que Novalis proclamou com clareza: "Mas o verdadeiro poeta sempre permaneceu um sacerdote, assim como o verdadeiro sacerdote sempre permaneceu um poeta - e não deveria o futuro nos trazer de volta esse antigo estado 
de coisas?" (NOVALIS, 1997, p. 36). E, reiterando: "No mundo antigo, religião já era até certo ponto o que se tornará para nós - poesia prática" (NOVALIS, 1997, p. 57). Proclamações românticas, cujo eco chega a Ginsberg: "Poeta é sacerdote".

\section{REFERÊNCIAS BIBLIOGRÁFICAS}

BIALE, David. Cabala e Contra-História: Gershom Scholem. Tradução de J. Guinsburg, São Paulo: Perspectiva, 2004.

Claudio Willer

BLAKE, William. Complete Writings. Editado por Geoffrey Keynes.

London: Oxford University Press, 1972.

BLAKE, William. O Casamento do Céu e do Inferno e outros escritos.

Tradução e notas de Alberto Marsicano. Porto Alegre: L\&PM Editores, 2007.

CALASSO, Roberto. A Literatura e os Deuses. Tradução de Jônatas Batista Neto. São Paulo: Companhia das Letras, 2004.

COHN, Norman, The Pursuit of the Millennium. Oxford University Press. 1981,

COHN, Sergio. (Org.), Geração Beat. Rio de Janeiro: Azougue, 2010.

DRAGÓ, Fernando Sánchez. Historia mágica del Camino de Santiago. Barcelona: Planeta, 2010.

ELIADE, Mircea, Initiation, rites, sociétés secrètes. Paris: Gallimard, 1999.

FRYE, Fearful Symmetry - A Study of William Blake.

GINSBERG, Allen. Allen Verbatim - Lectures on Poetry, Politics and Consciousness by Allen Ginsberg. Editado por Gordon Ball. New York: McGraw-Hill Paperbacks, 1974.

GINSBERG, Allen. Collected Poems 1947-1980. Nova York: Harper \& Row, 1988. 
GINSBERG, Allen. Morte à Orelha de Van Gogh! In: Uivo, Kaddish e outros poemas.

HANS, Jonas. The Gnostic Religion: The Message of the Alien God and the Beginnings of Christianity. Beacon Press, 1963.

HARPER, George Mills. Yeats's Golden Dawn, Wellingborough. Northamptonshire: The Aquarian Press, 1974.

William Blake, religião,

KAZIN, Alfred (Org). The portable Blake.New York: Penguin Books, 1976. misticismo e poesia

KEUROUAC. The origins of the Beat Generation, 1959.

MARINI, Ceci Batista. In.: TEIXEIRA, Faustino. (Org.). Caminhos da mística. São Paulo: Paulinas, 2012.

MCCLAIRE, Michael, A Nova Visão de Blake aos Beats. Tradução de Daniel Bueno, Luiza Leite e Sergio Cohn. Rio de Janeiro: Azougue, 2005.

NERVAL. Aurélia. Tradução de Augusto Contador Borges, Iluminuras, 1995.

NOVALIS, Philosophical Writings. Translated and edited by Margaret Mahony Stoljar. New York: State University of New York Press, Albany, 1997.

OLSON, Kirby. Gregory Corso: Doubting Thomist. Carbondale: Southern Illinois University Press, 2002.

PAZ, Octavio, Os Filhos do Barro. Tradução de Olga Savary. Rio de Janeiro: Nova Fronteira, 1984.

ROELOF Van den; HANEGRAAFF, Wouter J.. (editors), Gnosis and Hermeticism from Antiquity to Modern Times. State University of New York Press, 1998.

SCHOLEN, Gershom G.. On the Kabbalah and its Symbolism. New York: Schockem Books, 1965.

SNYDER, Gary. Re-habitar, 2005. 
SPENGLER, Oswald. A decadência do Ocidente. Edição condensada por Helmut Werner, tradução de Herbert Caro. Rio de Janeiro: Zahar, 1964.

WHITMAN, Walt. Folhas de relva. Tradução e posfácio de Rodrigo Garcia Lopes. São Paulo: Iluminuras, 2005.

WILLER, Claudio. Um obscuro encanto. 2010

. Geração Beat. 2010.

Claudio Willer

Recebido em 11 de agosto de 2015

Aceito em 20 de novembro de 2015

108 